\title{
Steroidogenic capacity of the placenta as a supplemental source of progesterone during pregnancy in domestic cats
}

\author{
Marta J Siemieniuch ${ }^{1 *}$, Ewelina Jursza', Anna Z Szostek', Dariusz J Skarzynski', Alois Boos² \\ and Mariusz P Kowalewski
}

\begin{abstract}
Background: Until recently, the corpus luteum (CL) was considered to be the main source of progesterone (P4) during pregnancy in the domestic cat (Felis catus). However, other possible sources of P4 have not been ruled out. Although feline placental homogenates were found to be capable of synthesizing P4, expression of the respective steroidogenic enzymes has not been investigated at the molecular level. Therefore, in the present study, expression of the two major factors involved in the synthesis of P4 - 3beta-hydroxysteroid dehydrogenase (3betaHSD) and steroidogenic acute regulatory protein (StAR) - was investigated in the feline $C L$ and placenta during the course of pseudopregnancy and pregnancy.
\end{abstract}

Methods: The mRNA levels of StAR and 3betaHSD were determined using Real Time PCR and their localizations were determined by immunohistochemistry. Placental P4 concentrations, after ethyl extraction, were measured by EIA.

Results: Luteal 3betaHSD and StAR mRNA levels were strongly time-dependent, peaking during mid-pregnancy. The placental 3betaHSD mRNA level was significantly upregulated towards the end of pregnancy. In the $\mathrm{CL}$, 3betaHSD and StAR protein were localized in the luteal cells whereas in the placenta they were localized to the maternal decidual cells. Placental P4 concentrations were low in early pregnant queens, but increased along with gestational age.

Conclusions: These results confirm that the placenta is an additional source of P4 in pregnant queens and can thereby be considered as an important endocrine organ supporting feline pregnancy.

Keywords: Placenta, Progesterone, Cat

\section{Background}

Female domestic cats (Felis catus) are traditionally classified as seasonally polyestrous with ovulation provoked by coitus $[1,2]$. However, in as many as $50 \%$ of domestic cats, ovulation occurs without cervical or vaginal stimulation $[3,4]$. If ovulation is not followed by pregnancy, the queen enters pseudopregnancy during which the corpora lutea (CL) remain active. Hence, the reproductive cycle in the domestic cat differs significantly from

\footnotetext{
* Correspondence: m.siemieniuch@pan.olsztyn.pl

'Department of Reproductive Immunology and Pathology, Institute of Animal Reproduction and Food Research of the Polish Academy of Sciences, Olsztyn 10-747, Tuwima-St. 10, Poland

Full list of author information is available at the end of the article
}

that in ungulates $[5,6]$ and dogs $[7,8]$, in which spontaneous ovulation is followed by the formation of $\mathrm{CL}$ in each estrous cycle. In the cat [9], rabbit [10] and rat [11], the luteal phase of non-pregnant animals lasts only one-half of a normal gestation. This means elevated progesterone $\left(\mathrm{P}_{4}\right)$ levels measured in circulating blood for 35-40 days in pseudopregnant and for approximately 60-65 days in pregnant queens. In contrast, in the dog [12], mink [13] and ferret [14], the length of the luteal phase is similar in the presence or absence of pregnancy. Progesterone levels in pregnant and non-pregnant dogs are similar within the first 60 days after ovulation [15]. Moreover, there are no indications of an active luteolytic principle in non-pregnant dogs, and, the canine CL

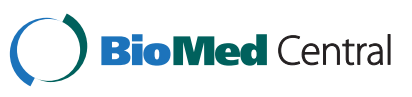


appears to be devoid of $\mathrm{PGF}_{2 \alpha}$-synthase (PGFS) activity $[16,17]$. Consequently, luteal regression in non-pregnant bitches seems to be a passive degenerative process in the absence of endogenous $\mathrm{PGF}_{2 \alpha}[16,17]$. The domestic cat thus seems to have a reproductive advantage over some other carnivores because its shorter luteal phase allows for an earlier return to estrual cyclicity. In the cat, ovarian activity returns within 7 to 10 days following pseudopregnancy [10]. The histological and endocrine patterns of early CL formation are the same in pregnant and pseudopregnant cats until days 10-12 after coitus [18]. However, after days 12-13, which coincides with the time of implantation $[19,20]$, plasma $\mathrm{P}_{4}$ concentration slowly declines in pseudopregnant queens, whereas during pregnancy it remains on a plateau until day 30 and then gradually declines towards the end of gestation [21].

Until the 1970s, the CL was considered to be the main source of $\mathrm{P}_{4}$ during feline gestation. However, the finding that ovariectomy in queens after day 45 either did not interrupt pregnancy [22] or only did in some animals [23] supported an assumption that the placenta is a source of steroidogenic enzymes [18]. Subsequently, feline placental homogenates were found to be capable of synthesizing $\mathrm{P}_{4}$ [19]; however, the expression of steroidogenic factors or $\mathrm{P}_{4}$ content has not been examined in the placenta to date.

Cholesterol is the precursor of all steroid hormones. Steroidogenesis is regulated by steroidogenic acute regulatory (StAR) protein, which controls cholesterol transport from the outer to the inner mitochondrial membranes of the steroidogenic cells [24]. Conversion of pregnenolone to $\mathrm{P}_{4}$ is a step catalyzed by $3 \beta$ - hydroxysteroid dehydrogenase/isomerase (3ßHSD). In this study, expression of these two factors was investigated in the feline $\mathrm{CL}$ and placenta throughout pregnancy and pseudopregnancy.

\section{Methods}

\section{Animals and tissue preservation}

All procedures were approved by the Local Animal Care and Use Committee in Olsztyn, Poland (No. 41/2007/N and 61/2010/DTN).

Privately owned queens $(n=36$, mixed breed, proven health status), aged $18 \pm 5$ months, housed individually or in pairs, with or without contact with an intact male, were enrolled in this study. No pharmacological treatment was performed to provoke ovulation in the animals. In the case of pregnant queens, an ovulation was provoked with coitus. Queens were checked daily for behavioral signs of estrus (treading of the hind feet, lordosis and tail deflection). The first day of silencing of estrus behavior in the queens was considered as Day 1 of the luteal phase. Reproductive tracts were collected from 13 pseudopregnant cats at early $(n=4$, days $3-5)$, mid ( $n=4$, days 10-15) and late phases of pseudopregnancy $(\mathrm{n}=5$, days $25-35)$, and from 12 pregnant cats at early $(n=5)$, mid $(n=4)$ and late $(n=3)$ gestation: $1.5-2$, 3-4 and 6-8 weeks after mating, respectively. For extraction of $\mathrm{P}_{4}$ from placentas, an additional 11 cats at different gestational ages were subjected to ovariohysterectomy (OHE), which was done with the owners' request and consent. The stage of the estrous cycle was further confirmed by endocrine analysis, according to the $\mathrm{P}_{4}$ values reported in the literature [10,25], and macroscopic observation of the ovaries and uterus. Before surgery, blood samples were collected from the cephalic vein into EDTA-containing tubes (Tyco Healthcare Group LP, Mansfield, USA) and transported to the laboratory at $4^{\circ} \mathrm{C}$. Plasma obtained after blood centrifugation $(3500 \mathrm{x} \mathrm{g}, 10 \mathrm{~min})$ was frozen at $-20^{\circ} \mathrm{C}$ until $\mathrm{P}_{4}$ measurement using direct enzyme immunoassay (EIA). Confirmation of gestational age was done according to the $\mathrm{P}_{4}$ values reported in the literature [18]. In addition, measurements of the crown-rump length in fetuses and uterine ampullae diameter or length were performed [26,27].

Tissues were washed immediately after surgery with sterile saline to remove blood contamination, then placed into fresh sterile saline at $4^{\circ} \mathrm{C}$ and transported to the laboratory within $1 \mathrm{~h}$. The $\mathrm{CL}$ were removed from a randomly selected ovary among the pairs belonging to the same luteal stage. The second ovary was fixed in buffered $4 \%$ formaldehyde for $24 \mathrm{~h}$, dehydrated and wax-embedded. Sections (2-3 $\mu \mathrm{m}$ thick) were used for evaluation of protein concentrations by immunohistochemistry. In pregnant animals, uterine horns were slit longitudinally and fragments of placenta were separated, washed in fresh saline to remove blood, preserved overnight at $4^{\circ} \mathrm{C}$ with RNAlater (Ambion Biotechnologie $\mathrm{GmbH}$, Wiesbaden, Germany), and then stored at $-80^{\circ} \mathrm{C}$ until total-RNA extraction. mRNA levels were determined using Real Time PCR, while localization of $3 \beta \mathrm{HSD}$ and StAR protein was examined by immunohistochemistry.

\section{Cloning of feline 3 $3 \mathrm{HSD}$ by reverse transcription (RT) and rapid amplification of CDNA ends polymerase chain reaction (RACE PCR)}

Total RNA was isolated from feline CL using Trizol Reagent according to the manufacturer's instructions (Gibco-BRL, Life Technologies, Karlsruhe, Germany). The whole procedure was carried out as described before for canine 3ßHSD [28]. For initial RT-PCR, $0.2 \mu \mathrm{g}$ of total RNA was used. An alignment of the known canine 3ßHSD sequence (GenBank accession number: AY739720) against the available online feline genomic sequence [29] was performed using BLAST $^{\circledR}$ software 
to obtain feline-specific PCR product (primers 1-2; Table 1). Integrity of RNA was checked by amplification of the housekeeping gene $\beta$-actin (primers $3-4$, Table 1).

First strand cDNA synthesis was performed with the PowerScript Reverse Transcriptase kit (BD Biosciences Clontech $\mathrm{GmbH}$, Heidelberg, Germany) using $0.6 \mu \mathrm{g}$ of total RNA. Subsequently, the SMART RACE cDNA Amplification kit (BD Biosciences Clontech $\mathrm{GmbH}$ ) was used with gene-specific primers (GSP, primers 5-6; Table 1) in combination with universal primer mix (UPM, primers 7-8; Table 1) supplied by the manufacturer of the SMART RACE Kit. Overlapping products of the missing cDNA coding fragments of the $5^{\prime}$ and $3^{\prime}$ ends were amplified. After initial denaturation at $94^{\circ} \mathrm{C}$ for $1 \mathrm{~min}$, the reactions were run for 35 cycles $\left(94^{\circ} \mathrm{C}\right.$ for $1 \mathrm{~min}$, annealing at $65^{\circ} \mathrm{C}$ for $2 \mathrm{~min}$, elongation at $72^{\circ} \mathrm{C}$ for $3 \mathrm{~min}$ ), and the final extension was at $72^{\circ} \mathrm{C}$ for $10 \mathrm{~min}$. Finally, RT-PCR for 40 cycles was performed at an annealing temperature of $57^{\circ} \mathrm{C}$ with specific primers (primers 9-10; Table 1) located at both ends of the open reading frame (ORF). All PCR products were visualized on a $1.5 \%$ ethidium bromide-stained gel, purified with a Qiaex II agarose gel extraction kit (Qiagen $\mathrm{GmbH}$, Hilden, Germany), ligated into pGEM-T vector (Promega, Dübendorf, Switzerland), multiplied in XL1 BLUE competent cells (Stratagene, La Jolla, CA, USA) and sequenced (Microsynth, Balgach, Switzerland). Finally, the cloned cDNA sequence was submitted to
GenBank with the accession number: JF794032, Felis catus $3 \beta$-hydroxysteroid dehydrogenase mRNA, complete cds.

\section{Cloning of feline StAR CDNA}

The procedure leading to characterization of feline StAR protein was carried out as previously described for canine StAR protein [30]. Total RNA was obtained from three feline CLs collected at early, mid and late phases of pseudopregnancy. The DNase- treatment was performed with RQ1 RNase free DNase (Promega), and the RT-PCR was done with the GeneAmp Gold RNA PCR kit (Perkin-Elmer Applied Biosystems GmbH, Weiterstadt, Germany), all as previously described [30]. Primers for qualitative PCR were obtained from the alignment of the canine sequence with GenBank accession number EF522840 using an online available feline genomic sequence. Using primer pairs (13-14; Table 1), a PCR product comprising $886 \mathrm{bp}$ of feline StAR protein was amplified. PCR conditions were as follows: initial denaturation at $95^{\circ} \mathrm{C}$ for $10 \mathrm{~min}$, then reactions were run for 40 cycles consisting of denaturation at $94^{\circ} \mathrm{C}$ for $1 \mathrm{~min}$, annealing at $56^{\circ} \mathrm{C}$ for $1.5 \mathrm{~min}$ and elongation at $72^{\circ} \mathrm{C}$ for $1.5 \mathrm{~min}$; the final extension was at $72^{\circ} \mathrm{C}$ for $10 \mathrm{~min}$. PCR products were visualized on a $1.5 \%$ ethidium bromide-stained gel, purified with the Qiaex II agarose gel extraction kit (Qiagen GmbH, Hilden, Germany), ligated into the pGEM-T vector (Promega) multiplied in XL1 BLUE competent cells (Stratagene,

Table 1 List of primers used for RT-PCR, RACE PCR and Real Time PCR

\begin{tabular}{|c|c|c|c|}
\hline Primer no. & Gene & Primer sequences & Accession number \\
\hline 1. & Initial 3ßHSD for RT-PCR & FWD 5'-TTGATACCCCGGTTTGACCA -3' & AY739720 \\
\hline 2. & Initial 3ßHSD for RT-PCR & REV 5'-TTGGCACCCCTAGATCAGTG - 3' & \\
\hline 3. & ACTB for RT-PCR & FWD 5'-ATCAAGGAGAAGCTGTGCTACGT-3' & AB51104 \\
\hline 4. & ACTB or RT-PCR & REV 5'-CGTTGCCGATGGTGATCA - $3^{\prime}$ & \\
\hline 5. & $3 \beta H S D$ RACE PCR GSP & FWD 5'-CACCAAAGCTATGATAACCTCAAT -3' & AY739720 \\
\hline 6. & $3 \beta H S D$ RACE PCR GSP & REV 5'-AGGCAAGCCAGTACTCCAGAAAT -3' & \\
\hline \multirow[t]{2}{*}{7.} & Universal Primer Mix (UPM) & FWD 5'-CTAATACGACTCACTATAGGGCAAGCAG & - \\
\hline & & TGGTATCAACGCAGAGT-3' & \\
\hline 8. & UPM & REV 5'-CTAATACGACTCACTATAGGGC-3' & AY739720 \\
\hline 9. & $3 \beta H S D$ for RT-PCR (ORF) & FWD 5'-TTGATACCCCGGTTTGACCA -3' & \\
\hline 10. & $3 \beta H S D$ for RT-PCR (ORF) & REV 5'-TTGGCACCCCTAGATCAGTG -3' & JF794032 \\
\hline 11. & 3ßHSD specific for Real Time PCR & FWD 5'-TCCCCAGTGTTTCTGATTCC $-3^{\prime}$ & \\
\hline 12. & 3ßHSD specific for Real Time PCR & REV $5^{\prime}$-CACCAACAAATGCACGATTC $-3^{\prime}$ & EF522840 \\
\hline 13. & Initial StAR for RT-PCR & FWD 5'-CAATGCTCCTAGCGACGTTC - -3' & \\
\hline 14. & Initial StAR for RT-PCR & REV 5'-AACAGTTGGAAGCAGCAGG -3' & \\
\hline 15. & StAR for Real Time PCR & FWD 5'-CCCATGGAGAGGCTTTATGA-3' & JF800676 \\
\hline 16. & StAR for Real Time PCR & REV 5'-CAACTCGTGGGTGATGACTG $-3^{\prime}$ & \\
\hline 17. & Cyclophilin for Real Time PCR & FWD 5'-CCTTCTGTAGCTCGGGTGAG $-3^{\prime}$ & AY029366 \\
\hline 18. & Cyclophilin For Real Time PCR & REV 5'-CTTGGAGGGGAGGTAAGGAG $-3^{\prime}$ & \\
\hline
\end{tabular}


La Jolla, CA, USA) and sequenced (Microsynth, Balgach, Switzerland). The cloned cDNA sequence was submitted to GenBank with the accession number JF800676 (Felis catus Steroidogenic Acute Regulatory protein (StAR) mRNA cds).

\section{Real Time PCR}

The levels of mRNA expression of target genes were examined by Real-Time PCR using specific primers for $3 \beta H S D$, StAR and cyclophilin (Cyc). Among several different genes, including $\beta$-Actin, GAPDH and $C y c$, the last one was employed as a reference because the differences in $C y c$ expression between different samples did not exceed two cycles. All primers were purchased from Microsynth (Balgach, Switzerland). The forward and reverse sequences used for quantitative Real-Time PCR and the GenBank accession numbers are given in Table 1 (primers 11-12, 15-16 and 17-18). The Real-Time PCR reactions were carried out in an automated fluorometer ABI PRISM ${ }^{\circledR} 7300$ Sequence Detection System (Applied Biosystems, Darmstadt, Germany) using SYBR Green Master Mix (Applied Biosystems, Applera, Warsaw, Poland). PCR reactions were performed in 96-well plates. The total reaction volume was $20 \mu \mathrm{l}$ containing: $1 \mu \mathrm{l}$ cDNA (200 ng), $250 \mathrm{nM}$ each of forward and reverse primers, and $10 \mu \mathrm{l} \mathrm{SYBR}$ Green PCR Master Mix. Real time PCR was carried out as follows: initial denaturation $\left(10 \mathrm{~min}\right.$ at $\left.95^{\circ} \mathrm{C}\right)$, followed by 40 cycles of denaturation $\left(15 \mathrm{~s}\right.$ at $\left.95^{\circ} \mathrm{C}\right)$ and annealing $\left(1 \mathrm{~min}\right.$ at $\left.60^{\circ} \mathrm{C}\right)$. After each PCR reaction, melting curves were obtained by stepwise increases in temperature from 60 to $95^{\circ} \mathrm{C}$ to ensure single product amplification. The presence of the product was also confirmed by electrophoresis on $2 \%$ agarose gel. Relative quantification was performed by normalizing the signals of target genes with the Cyc signal by the Miner method for quantifying qRT-PCR results using calculations based on the kinetics of individual PCR reactions [31].

\section{Immunohistochemistry}

Immunohistochemistry was done according to the procedure described by Kowalewski et al. [30]. Firstly, the sections were deparaffinized and rehydrated, and then incubated in citrate buffer (10 nM, pH 6.0) for $15 \mathrm{~min}$ under microwave irradiation at $560 \mathrm{~W}$ for antigen retrieval. After cooling for $20 \mathrm{~min}$ at $20^{\circ} \mathrm{C}$, sections were incubated in $0.3 \% \mathrm{H}_{2} \mathrm{O}_{2}$ in methanol for $30 \mathrm{~min}$ to quench endogenous peroxidase and then washed in IHC-buffer/0.3\% Triton $\mathrm{X}$ pH 7.2-7.4 $(0.8 \mathrm{mM}$ $\mathrm{Na}_{2} \mathrm{HPO}_{4}, 1.47 \mathrm{mM} \mathrm{KH} \mathrm{PO}_{4}, 2.68 \mathrm{mM} \mathrm{KCl}, 1.37 \mathrm{mM}$ $\mathrm{NaCl}$ ). To block nonspecific binding sites, sections were incubated in $10 \%$ goat or horse serum. The first primary antibody (dilution 1:5000) was a rabbit polyclonal antiserum against human placental 3ßHSD that was kindly donated by Dr I.J. Mason (Clinical Biochemistry, Centre for Reproductive Biology, University of Edinburgh) [32]. The second primary antibody (dilution 1:3000) was a rabbit polyclonal antibody against StAR protein. This was an antipeptide antiserum against amino acids 88-98 of mouse StAR protein kindly donated by Dr. Douglas M. Stocco (Texas Tech University Health Sciences Center, Lubbock, US) [33]. Serum from a nonimmunized rabbit served as an isotype control. The third primary antibody (dilution 1:100) was a mouse monoclonal anti-vimentin clone 3B4 (DakoCytomation, Glostrup, Denmark). Vimentin was used to identify cells of mesenchymal origin (e.g., maternal decidual cells, fibroblasts or blood vessels) and distinguish them from nonmesenchymal cells such as fetal trophoblast cells, in the placenta [34]. Sections were incubated overnight at $4^{\circ} \mathrm{C}$, then washed in IHC-buffer and incubated with biotinylated goat IgG (secondary antibody, dilution 1:100) against rabbit immunoglobulin (Vector Laboratories, Burlingame, US) (used as a secondary antibody for the sections stained against StAR and 3 $\beta \mathrm{HSD}$ ) or biotinylated horse IgG (secondary antibody, dilution 1:200) against mouse immunoglobulin (Vector Laboratories, Burlingame, US) (used as a secondary antibody for the sections stained against vimentin). Then the sections were incubated with the avidin-biotin-peroxidase complex (Vectastain ABC kit, Vector Laboratories, Burlingame, US) for $30 \mathrm{~min}$ at $20^{\circ} \mathrm{C}$. After washing with IHC-buffer, sections were allowed to react with the substrate diamino-benzidine (DAB; DakoCytomation, Glostrup, Denmark) according to the manufacturer's instructions. The reactions were arrested by dipping the sections under running tap water for $5 \mathrm{~min}$. Hematoxylin was used to counterstain the sections, then they were mounted in Histokit (Assistant, Osterode, Germany).

Isotype control was done to avoid false positive results. The luteal and placental sections were incubated with serial dilutions of pre-immunized rabbit serum (starting at 1:1000) or pre-immunized mouse serum (starting at 1:50). No positive staining was observed at a 1:3000 dilution of pre-immunized rabbit serum or at a 1:100 dilution of pre-immunized mouse serum.

\section{Placental progesterone extraction}

Progesterone extraction was carried out using a modification of a methoddescribed previously [35]. Placenta samples were stored at $-80^{\circ} \mathrm{C}$. The tissues $(200-300 \mathrm{mg}$ each) were thawed and homogenized in glass vials using a tissue disruptor with $400 \mu \mathrm{l}$ EIA buffer containing $45 \mu \mathrm{l} 1 \mathrm{~N} \mathrm{HCl}$. Next, $3 \mathrm{ml}$ of ethyl petroleum was added to each sampleand it was shaken for $10 \mathrm{~min}$, then samples were incubated at $-20^{\circ} \mathrm{C}$ for $4 \mathrm{~h}$. Afterwards, the supernatant was collected and evaporated to dryness under nitrogen at $40^{\circ} \mathrm{C}$. Finally, $400 \mu \mathrm{l}$ of EIA buffer with 


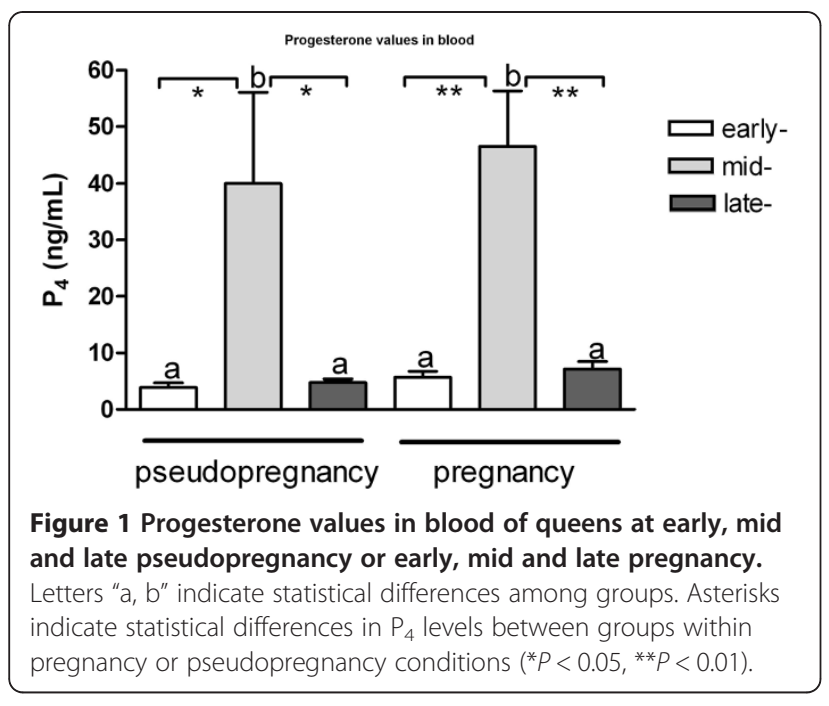

$0.1 \%$ BSA was added. The suspension was frozen at $-20^{\circ} \mathrm{C}$ until $\mathrm{P}_{4}$ measurement by EIA.

\section{Progesterone determination}

Assessment of $\mathrm{P}_{4}$ concentration in plasma followed the methodology previously described [36]. Horseradish peroxidase-labeled $\mathrm{P}_{4}$ was used at a final dilution of 1:75.000. Anti- $\mathrm{P}_{4}$ serum (final dilution of 1:100 000) was kindly donated by Dr. Stanisław Okrasa, University of Warmia and Mazury, Olsztyn, Poland. The $\mathrm{ED}_{50}$ for $\mathrm{P}_{4}$ was $4.2 \mathrm{ng} / \mathrm{mL}$ and the assay ranged from 0.39 to $100 \mathrm{ng} / \mathrm{mL}$. The intra- and inter-assay CVs were $4.2 \%$ and $9.3 \%$, respectively. Progesterone concentration in plasma was expressed as $\mathrm{ng}$ per $\mathrm{mL}(\mathrm{ng} / \mathrm{mL})$ and in placenta as ng per $\mathrm{g}(\mathrm{ng} / \mathrm{g})$.

\section{Statistics}

To test the effect of different stages of pregnancy or pseudopregnancy on mRNA levels, the Kruskal-Wallis Test (a nonparametric ANOVA) was used followed by the Newman-Keuls Multiple Comparison Test using the statistical software program GraphPad5 (GraphPad PRISM v 5.0; GraphPad Software Inc., San Diego, CA, USA). Progesterone concentrations in plasma are shown as a mean \pm standard deviation. To test the effect of the presence or absence of pregnancy on circulating $\mathrm{P}_{4}$ concentrations within each luteal phase, a nonparametric ANOVA was used followed by the Newman-Keuls Multiple Comparison Test. Significance was defined as values of $P<0.05$.

\section{Results}

Determination of pregnancy or pseudopregnancy stages Queens were considered to be at the early luteal phase when the plasma $\mathrm{P}_{4}$ was between 2 to $8 \mathrm{ng} / \mathrm{mL}$ and
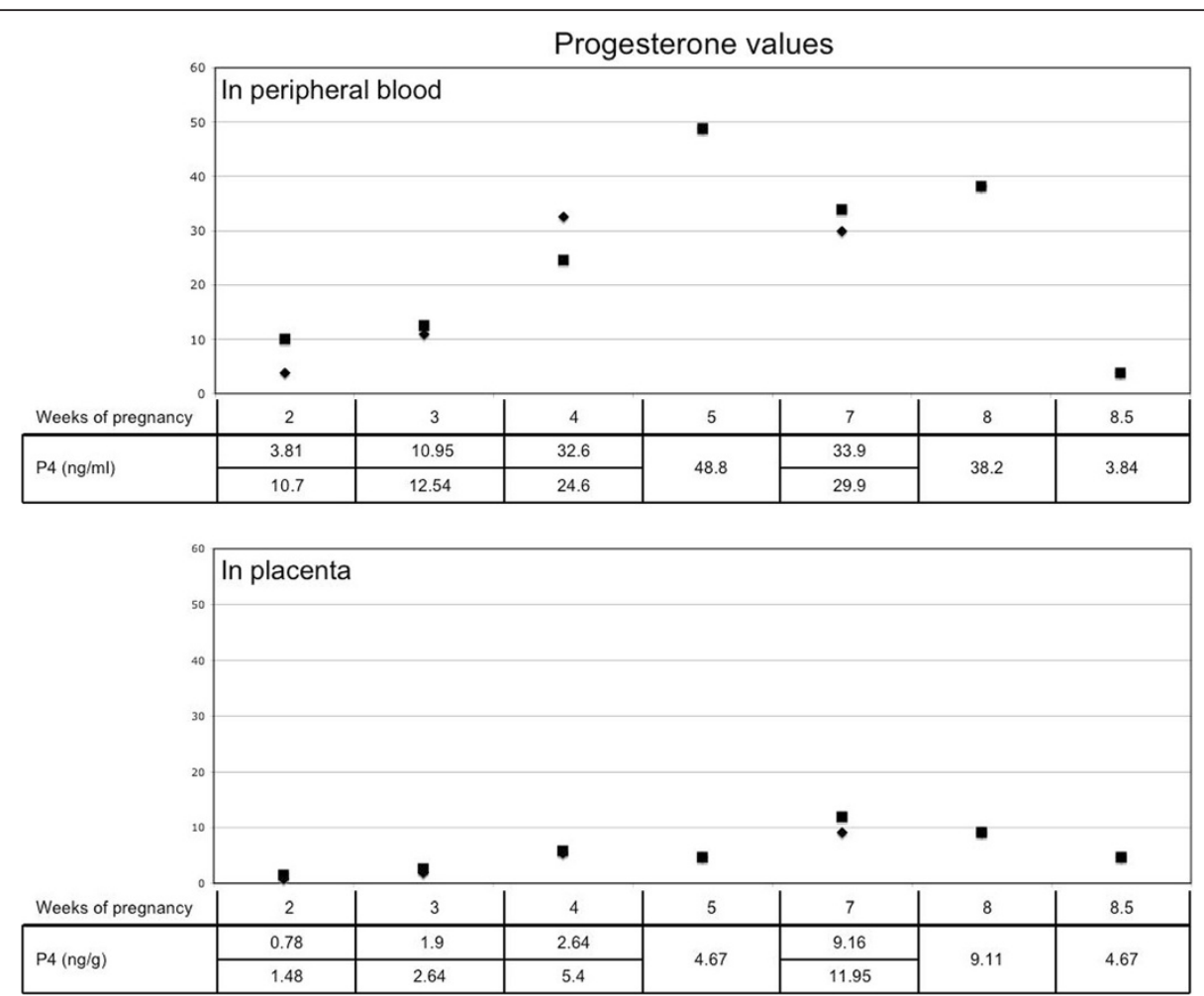

Figure 2 Progesterone values in blood and placenta. Progesterone values in blood (upper part) and placenta (lower part) in cats ovariectomized at different weeks of pregnancy. 
the corpora haemorrhagica were $\geq 2 \mathrm{~mm}$ in diameter. Mid-pseudopregnancy was determined when plasma $\mathrm{P}_{4}$ was $>17 \mathrm{ng} / \mathrm{mL}$ and $\mathrm{CL}$ were reddish and 3-4 $\mathrm{mm}$ in diameter. Late pseudopregnancy was characterized by plasma $\mathrm{P}_{4}<5 \mathrm{ng} / \mathrm{mL}$ and the presence of pale CL. The queens were considered to be at early, mid and late pregnancy when the plasma $P_{4}$ was between 2 to $8,>20$ or $<$ $12 \mathrm{ng} / \mathrm{mL}$, respectively. Progesterone concentrations in plasma are shown in Figure 1 . The serum $\mathrm{P}_{4}$ concentration was $3.9 \pm 1.4 \mathrm{ng} / \mathrm{mL}, 39.9 \pm 32.2 \mathrm{ng} / \mathrm{mL}$ and $4.2 \pm 1.2 \mathrm{ng} / \mathrm{mL}$ in queens at early, mid and late pseudopregnancy, respectively; and $5.4 \pm 2.3 \mathrm{ng} / \mathrm{mL}, 46.5 \pm$ $19.6 \mathrm{ng} / \mathrm{mL}$ and $5.3 \pm 6.4 \mathrm{ng} / \mathrm{mL}$ in queens at early, mid and late pregnancy, respectively. No statistical differences were seen within each luteal phase examined with respect to the presence or absence of pregnancy $(\mathrm{P}>0.05)$. Placental $\mathrm{P}_{4}$ contents depended on the gestational age and are shown in Figure 2. The amount of extracted $\mathrm{P}_{4}$ was $1.7 \pm 0.77 \mathrm{ng} / \mathrm{g}, 5.5 \pm 0.58 \mathrm{ng} / \mathrm{g}$ and $8.7 \pm 3.01 \mathrm{ng} / \mathrm{g}$ of tissue from early, mid and late pregnant queens, respectively.

StAR- and 3ßHSD- mRNA levels in the feline $\mathrm{CL}$ and placenta Luteal StAR mRNA was strongly time-dependent, with significantly elevated mRNA-levels observed during

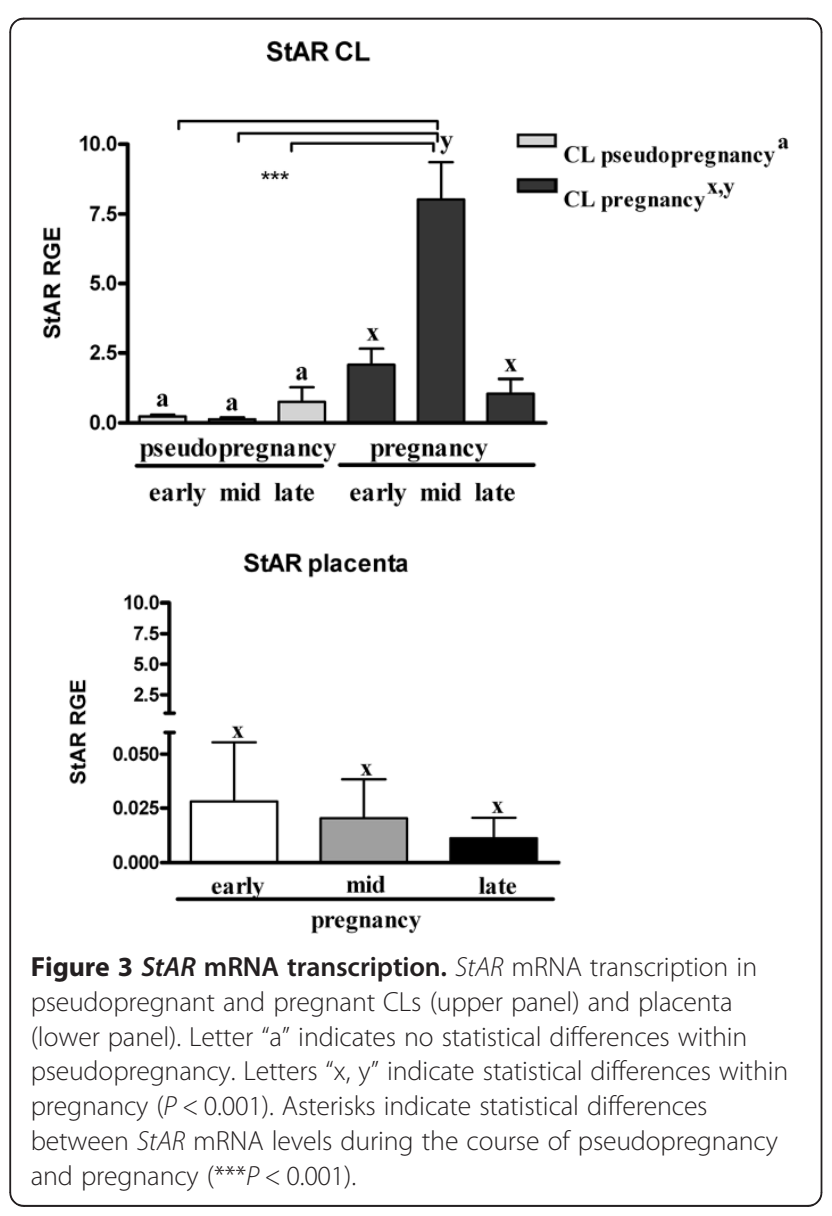

mid-pregnancy $(P<0.001)$ (Figure 3$)$. No statistically significant changes were observed among placental StAR-mRNAs detected at early, mid and late gestation (Figure 3).

Luteal $3 \beta H S D$ mRNA expression was also strongly time-dependent, with significantly elevated mRNA levels observed during mid-pseudopregnancy $(\mathrm{P}<0.05)$ and mid-pregnancy $(\mathrm{P}<0.01)$ (Figure 4$)$. Placental $3 \beta H S D$ mRNA was significantly up-regulated towards the end of pregnancy $(\mathrm{P}<0.01)$ (Figure 4$)$.

\section{Localization of StAR protein and 3ßHSD in the feline CL and placenta}

The spatial localizations of StAR and 3BHSD proteins in the gestational $\mathrm{CL}$ and placenta are shown in Figures 5 and 6 , respectively. Within the CL, StAR and 3ßHSD protein were localized in the luteal cells (Figure 5A and $5 \mathrm{~B}$, respectively). Immunostaining against StAR protein and 3ßHSD was observed in early, mid and late pseudopregnancy $\mathrm{CL}$, as well as in early, mid and late pregnancy CL. Based on comparison with the pattern of staining with vimentin (Figure 6B), the placental cells in which StAR (Figure 6C) protein and 3 $3 \mathrm{HSD}$ (Figure 6D) were immunolocalized were identified as cells of

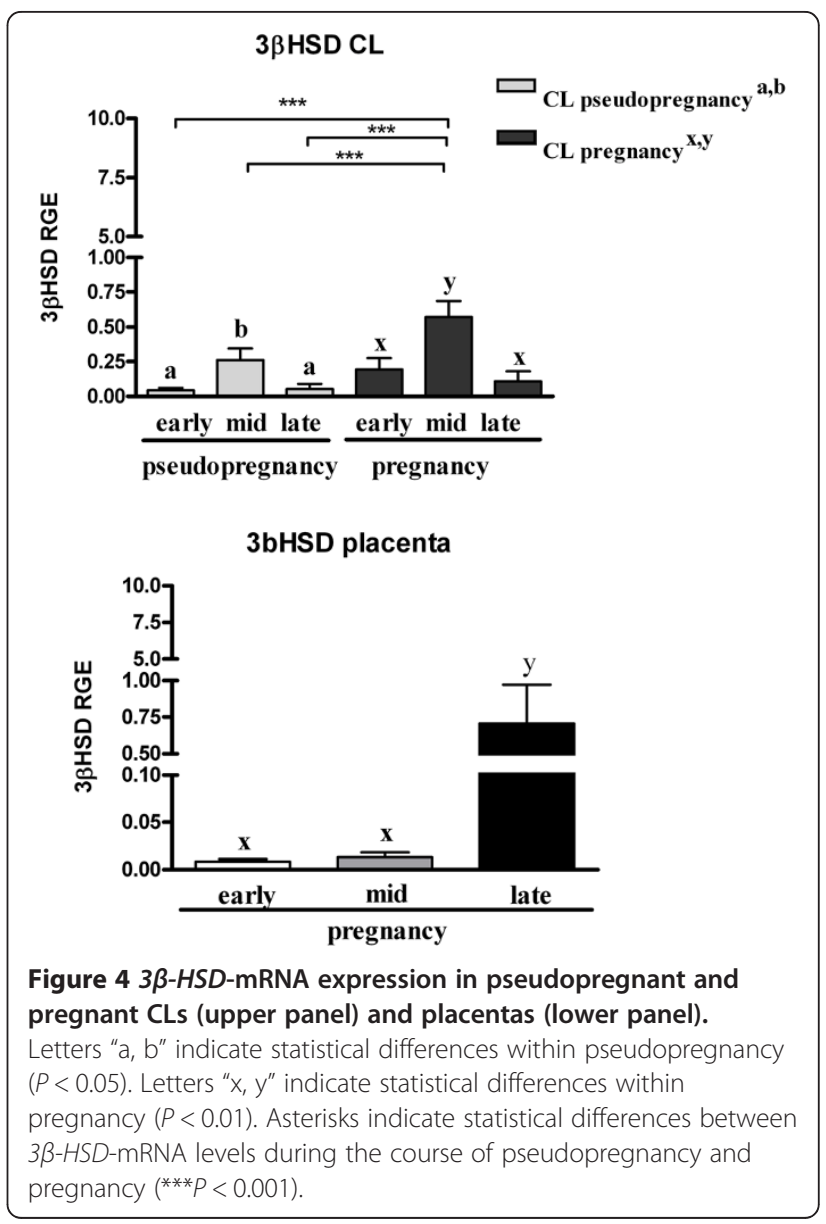



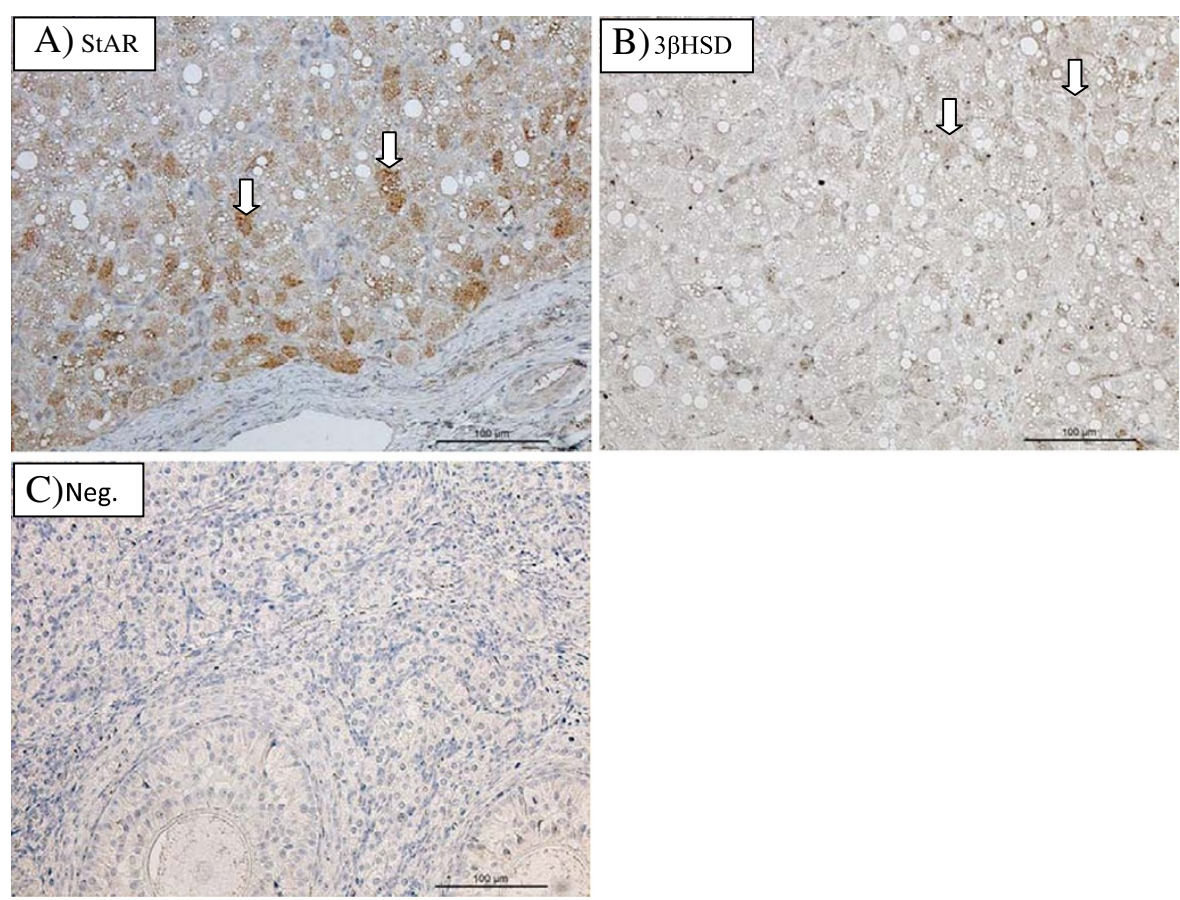

Figure 5 StAR (A) and 3ßHSD (B) protein expression and negative control (C) in CL. Tissue collected at $8^{\text {th }}$ week of pregnancy. Arrows show luteal cells. Bar represents $100 \mu \mathrm{m}$.

mesenchymal origin such as maternal decidual cells (Figure 6B). Positive staining against both proteins examined was generally observed in mid and late pregnancy placentas. A slight positive staining against 33HSD was also observed in the fetal component of the placentas.

\section{Discussion}

The present results confirm that the placenta is an additional source of $\mathrm{P}_{4}$ in pregnant queens, possibly acting as an important endocrine organ during pregnancy. Both StAR and $3 \beta H S D$ were immunolocalized in the placenta and $C L$ in each luteal phase. In the present study, the luteal $3 \beta H S D$ mRNA expression patterns in pregnant and pseudopregnant animals were similar, both peaking during the mid-luteal phase. However, luteal mRNA was 2.5 -fold higher in pregnant than in pseudopregnant queens. Luteal StAR mRNA remained at a relatively constant low level in pseudopregnant animals, but followed the pattern of $3 \beta H S D$ mRNA expression in pregnant animals. However, no quantitative assessment was performed for the expression of StAR and 3BHSD at the protein level.

A rapid development of the $\mathrm{P}_{4}$-producing $\mathrm{CL}$ is observed in both pregnant and pseudopregnant cats. Plasma $\mathrm{P}_{4}$ levels are about the same in pregnant and pseudopregnant queens in the first 10-12 days after coitus [18] but their profiles diverge as early as on day 12 or day 13 after coitus, which is the period of implantation in the cat $[18,20]$. The luteal StAR- and $3 \beta H S D$ mRNA were highest during the mid-phase of pregnancy. Additionally, increased $3 \beta H S D$-levels were also observed at the mid-phase of pseudopregnancy. The high expression of both factors during both mid-luteal phases may be responsible for the strongly elevated $\mathrm{P}_{4}$ levels in the circulating blood reported previously $[2,18,21,37]$ and observed also in the present study. As reported previously, $\mathrm{P}_{4}$ values rose rapidly in pseudopregnant queens between Day 4 and Day 9, peaking around Day 14 postovulation with a plateau between Day 9 and Day 23. The range of serum $\mathrm{P}_{4}$ concentrations at that time was $30 \mathrm{ng} / \mathrm{mL}$ to more than $87 \mathrm{ng} / \mathrm{mL}$ [2]. The present results concur with data reported earlier, in which strong individual variations in plasma $\mathrm{P}_{4}$ concentrations were observed. In one queen experiencing a nongravid luteal phase, $\mathrm{P}_{4}$ peaked at $88 \mathrm{ng} / \mathrm{mL}$, vs. a range of 20.1$28.7 \mathrm{ng} / \mathrm{mL}$ observed in other animals. The mean value of plasma $\mathrm{P}_{4}$ observed in queens at the mid-luteal stage was $39.9 \mathrm{ng} / \mathrm{mL}$ and is consistent with the those reported in the literature [2]. However, in another study, $\mathrm{P}_{4}$ values in pseudopregnant cats were shown to peak at levels of $17 \mathrm{ng} / \mathrm{mL}$ on Day 18 postcoitum, followed by a gradual decline to values $<1 \mathrm{ng} / \mathrm{mL}$ between Days 30-46 after coitus [25]. In pseudopregnant queens at the late luteal stage, we usually observed distinctly diminished $\mathrm{P}_{4}$ values compared to the mid luteal phase. Wildt and coworkers [2] reported that the serum $\mathrm{P}_{4}$ values were 

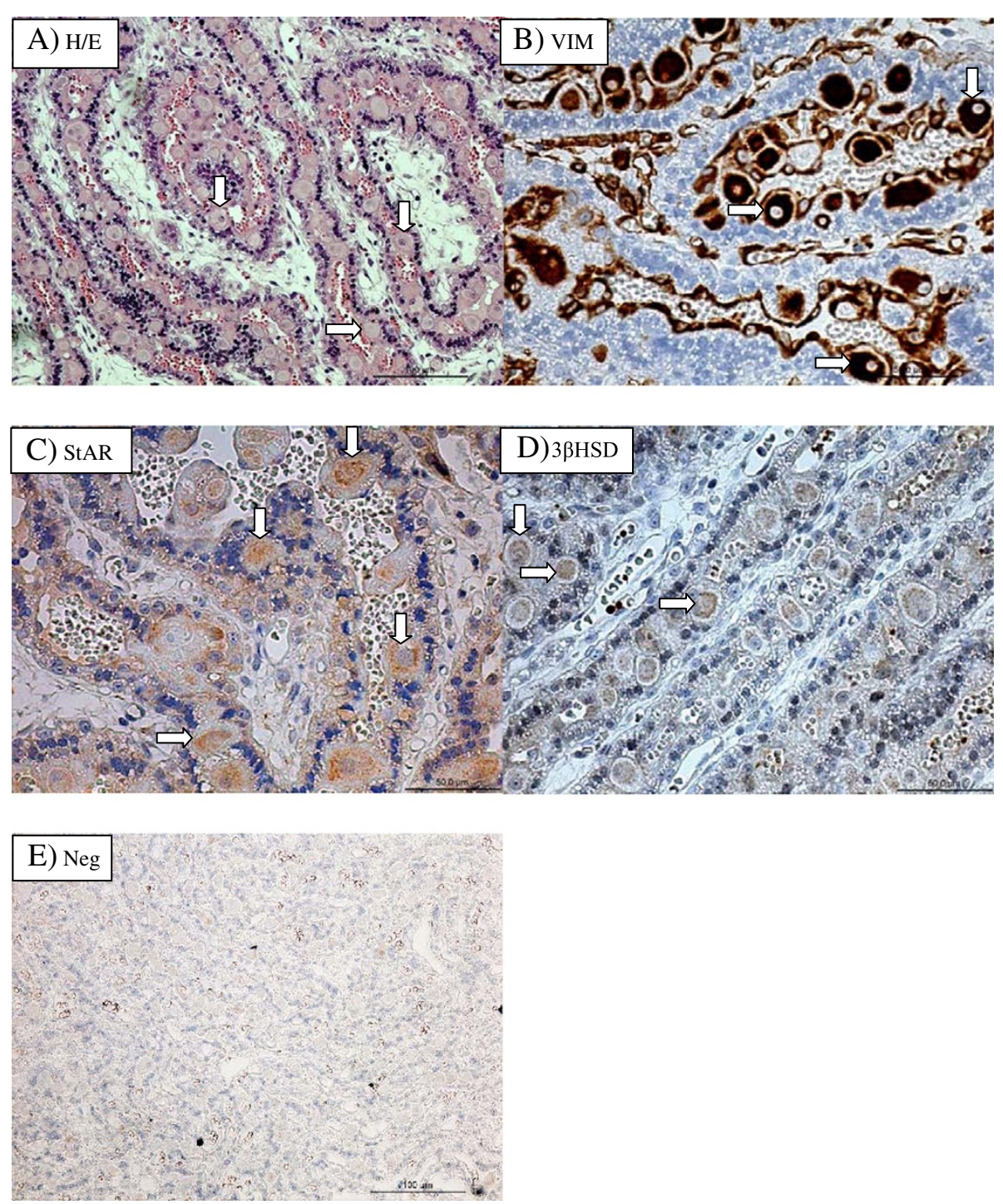

Figure 6 Hematoxylin/eosin (A) staining and vimentin (B) protein expression, StAR (C) and 3BHSD (D) protein expression and negative control (E) in placentas collected at the $\mathbf{8}^{\text {th }}$ week of pregnancy. Arrows show maternal decidual cells. Bar represents $50 \mu \mathrm{m}$ in the Figure showing staining for vimentin, StAR and 3BHSD or $100 \mu \mathrm{m}$ in the Figure showing staining with hematoxylin/eosin and negative control.

lower than $1 \mathrm{ng} / \mathrm{mL}$ by Day 42 post ovulation, however, CL remnants were visually evident throughout the following interestrus period. In the present study, the $\mathrm{P}_{4}$ values in plasma reached approximately $4.2 \pm 1.2 \mathrm{ng} / \mathrm{mL}$. However, blood samples were collected from pseudopregnant queens only from Day 25 to Day 35 (Day 1 signified the first day of pseudopregnancy and was consistent with silencing of estrus behavior), so this difference might explain the discrepancy in observed $\mathrm{P}_{4}$ values.

During mid-pregnancy, the serum $\mathrm{P}_{4}$ values varied significantly between individual cats (range 34 $74.4 \mathrm{ng} / \mathrm{mL}$ ), with a mean $\mathrm{P}_{4}$ concentration of $46.5 \mathrm{ng} /$ $\mathrm{mL}$. Although $\mathrm{P}_{4}$ concentrations in the blood of midpregnant queens were numerically higher than in non- pregnant animals in the mid-luteal phase, no statistical differences were seen in the present study between these two groups. It cannot be ruled out that these results might differ significantly if the number of females in each group were increased; however, it should also be mentioned that the present data are very similar to those reported by others (for review see: 2,37 ). Distinct individual variations in the plasma $\mathrm{P}_{4}$ levels collected from pregnant cats were previously reported [37], i.e., peak serum $\mathrm{P}_{4}$ from 13.5 to $57 \mathrm{ng} / \mathrm{mL}$ extending over Days 11 to 60 in individual females. After peripheral $\mathrm{P}_{4}$ peaked, a gradual decline began, usually at Day 44 in most of the queens that were examined. The $\mathrm{P}_{4}$ levels were maintained at a relatively constant level until a few days before parturition, when they sharply decreased [37]. In 
the present study, serum $\mathrm{P}_{4}$ decreasing to values lower than $10 \mathrm{ng} / \mathrm{mL}$ (range $3.8-9.2 \mathrm{ng} / \mathrm{mL}$ ) was observed in queens in the $7^{\text {th }}$ and $8^{\text {th }}$ week of pregnancy; however, in three individuals at the $6^{\text {th }}$ and $7^{\text {th }}$ week of pregnancy, the $\mathrm{P}_{4}$ values were still near $30 \mathrm{ng} / \mathrm{mL}$. Summarizing these data, it might be concluded that, besides visible differences existing in plasma $\mathrm{P}_{4}$ levels between individuals, the distinct decrease in peripheral $\mathrm{P}_{4}$ precedes onset of parturition.

The successful extraction of $\mathrm{P}_{4}$ from the placenta further supports its role as an additional source of $\mathrm{P}_{4}$ during pregnancy in the cat. Placental $\mathrm{P}_{4}$ concentrations seem to be dependent on gestational age. Thus, the higher $\mathrm{P}_{4}$ values reported for pregnant queens may result from $\mathrm{P}_{4}$ supplementation by placental tissue, as hypothesized previously [18]. Still remaining, however, is the question whether the placenta-originating $\mathrm{P}_{4}$ would be alone able to maintain pregnancy in domestic cats ovariectomized after 45 days of pregnancy. In contrast to cats, in mice it was proven that ovariectomy at any time of pregnancy causes abortion [38]. It was thought that $\mathrm{P}_{4}$ synthesis is not possible de novo in the rodent placenta. Nevertheless, trophoblast giant cells from mouse placenta were shown to produce $\mathrm{P}_{4}$ from cholesterol [39]. Moreover, recent studies using molecular tools have shown that $\mathrm{P}_{4}$ synthesis is possible in rodent maternal decidual cells and occurs upon decidualization, but is terminated at mid-gestation [40]. It is further assumed that this local synthesis of $\mathrm{P}_{4}$ may act as an immunosuppressive factor at the implantation sites [41]. In contrast in cows placenta-derived progesterone and oestrone are supposed to be auto- or paracrine factors involved in placental growth and differentiation [42]. The synthesis of $\mathrm{P}_{4}$ was recently demonstrated in uninucleate trophoblast cells and the trophoblast giant cells of the bovine placenta; however, these two kinds of cells were reported to have different steroidogenic capacities [43].

The morphological comparative study in the epitheliochorial and endotheliochorial placenta types published by Leiser and coworkers in 1998 [44] presents a photograph of the typical labyrinthine-like system in the cat placenta with very easily visible and differentiated decidual cells [44]. In the present study, anti-vimentin staining was applied in order to distinguish between cells of mesenchymal origin and other sources, as described and confirmed for the canine and feline placenta by Bezler [34]. Since the StAR- and 3ßHSD-positive placental cells were identified as maternal decidual cells, and were found mostly in placentas from the second half of gestation, the present findings on the spatio-temporal expression of the key steroidogenic genes differ from data obtained for other species. Even though some 3ßHSDpositive cells were observed in the trophoblast, the strongest signals were present in decidual cells suggesting that these cells may be the main source of steroid synthesis within the feline placenta. Although the reproductive biology characteristics of the dog and cat are often compared, especially on this point distinct differences are observed, because in dogs the CL is the only source of $\mathrm{P}_{4}$ during both pseudopregnancy and pregnancy [7].

\section{Conclusions}

The cellular localization of the steroidogenic factors that are present in the feline placenta differs from their localizations in rodents and cows. The present data confirm previous observations that the feline placenta is a supplemental source of $\mathrm{P}_{4}$ and could be important for the maintenance of pregnancy in this species.

\section{Competing interests}

The authors declare that they have no competing interests.

\section{Authors' contributions}

MJS conceived of the study, and participated in its design, carried out molecular genetic studies and drafted the manuscript. EJ and AZS carried out the immunoassays and participated in molecular studies. AB and DJS helped to draft the manuscript. MPK participated in the design of the study and interpretation of the results, carried out the molecular and genetic studies, provided the knowledge- and methods-transfer and helped to draft the manuscript. The study was partially financed from the Institute of Veterinary Anatomy, University of Zurich, Zurich, Switzerland. All authors read and approved the final 552 manuscript.

\section{Acknowledgements}

This study was supported by Grants-in-Aid for Scientific Research from the Polish Ministry of Scientific Research and High Education (IP2010 037570 and IP2011 048971) and was partially financed from the Institute of Veterinary Anatomy, University of Zurich, Zurich, Switzerland. Authors are indebted to Dr lan J. Mason, Centre for Reproductive Biology, University of Edinburgh, for donation of rabbit immunoprotein against recombinant human type II 3ßHSD (R1484); Dr Douglas M. Stocco, Department of Cell Biology and BiochemistryTexas Tech University Health Sciences Center, Lubbock, Texas, for donation of rabbit immunoprotein against StAR; Dr Stanislaw Okrasa, University of Warmia and Mazury, Olsztyn for donation of $\mathrm{P}_{4}$-antibodies, and to Elisabeth Högger and Urs Büchler, Institute of Veterinary Anatomy, Vetsuisse Faculty, University of Zurich, Zurich, Switzerland for their excellent technical help, and Dr. Barry Bavister for help with editing this manuscript.

\section{Author details}

'Department of Reproductive Immunology and Pathology, Institute of Animal Reproduction and Food Research of the Polish Academy of Sciences, Olsztyn 10-747, Tuwima-St. 10, Poland. ${ }^{2}$ Institute of Veterinary Anatomy, Vetsuisse Faculty, University of Zurich, Winterthurerstrasse 260,

$\mathrm{CH}-8057$ Zurich, Switzerland.

Received: 12 March 2012 Accepted: 17 August 2012

Published: 30 October 2012

\section{References}

1. Concannon PW, Hodgson B, Lein D: Reflex LH release in estrous cats following single and multiple copulations. Biol Reprod 1980, 23:111-117.

2. Wildt DE, Chan SY, Seager SW, Chakraborty PK: Ovarian activity, circulating hormones, and sexual behavior in the cat. I. Relationships during the coitus-induced luteal phase and the estrous period without mating. Biol Reprod 1981, 25:15-28.

3. Lawler DF, Johnston SD, Hegstad RL, Keltner DG, Owens SF: Ovulation without cervical stimulation in domestic cats. J Reprod Fertil 1993, 47(Suppl):57-61. 
4. Pelican KM, Brown JL, Wildt DE, Ottinger MA, Howard JG: Short term suppression of follicular recruitment and spontaneous ovulation in the cat using levonorgestrel versus $\mathrm{GnRH}$ antagonist. Gen Comp Endocrin 2005, 144:110-121.

5. McCracken JA, Custer EE, Lamsa JC: Luteolysis: a neuroendocrinemediated event. Physiol Rev 1999, 79:263-323.

6. Okuda K, Miyamoto Y, Skarzynski DJ: Regulation of endometrial prostaglandin F2a synthesis during luteolysis and early pregnancy in cattle. Dom Anim Endocrin 2002, 23:255-264.

7. Concannon PW, McCann JP, Temple M: Biology and endocrinology of ovulation, pregnancy and parturition in the dog. J Reprod Fertil 1989, 39(Suppl):3-25.

8. Hoffmann B, Höveler R, Hasan SH, Failing K: Ovarian and pituitary function in the dog following hysterectomy. J Reprod Fertil 1992, 96:837-845.

9. Paape SR, Shille VM, Seto H, Stabenfeldt GH: Luteal activity in the pseudopregnant cat. Biol Reprod 1975, 13:470-474

10. Horrel E, Kilpatrick PW, Smith BM: Progestational steroids during pseudopregnancy in the rabbit. J Endocr 1972, 55:89-96.

11. Pepe GJ, Rothchild I: A Comparative Study of Serum Progesterone Levels in Pregnancy and in Various Types of Pseudopregnancy in the Rat. Endocrinology 1974, 95:275-279.

12. Smith MS, MC Donald LE: Serum levels of luteinizing hormone and progesterone during the estrous cycle, pseudopregnancy and pregnancy in the dog. Endocrinology 1974, 94:404-412.

13. Allais $C$, Martinet $L$ : Relation between daylight ratio, plasma progesterone levels and timing of nidation in mink (Mustela vison). J Reprod Fertil 1978, 54:133-136.

14. Heap RB, Hammond J Jr: Plasma progesterone levels in pregnant and pseudopregnant ferrets. J Reprod Fertil 1974, 39:149-152.

15. Concannon PW, Butler WR, Hansel W, Knight PJ, Hamilton JM: Parturition and lactation in the bitch: serum progesterone, cortisol and prolactin. Biol Reprod 1978, 19:1113-1118.

16. Hoffmann B, Büsges F, Engel E, Kowalewski MP, Papa P: Regulation of corpus luteum-function in the bitch. Reprod Dom Anim 2004, 39:232-240.

17. Kowalewski MP, Mutembei HM, Hoffmann B: Canine prostaglandin F2a receptor (FP) and prostaglandin F2a synthase (PGFS): molecular cloning and expression in the corpus luteum. Anim Reprod Sci 2008, 107:161-175.

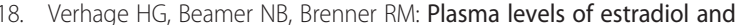
progesterone in the cat during polyestrus, pregnancy and pseudopregnancy. Biol Reprod 1976, 14:579-585.

19. Malassiné A, Ferré F: Delta 5,3 beta Hydroxysteroid dehydrogenase activity in cat placental labyrinth: evolution during pregnancy, subcellular distribution. Biol Reprod 1979, 21:965-971. 1980

20. Boomsma RA, Mavrogianis PA, Verhage HG: Changes in endometrial and placental protein synthesis and morphology during pregnancy and pseudopregnancy in the cat. Biol Reprod 1991, 44:345-356.

21. Tsutsui T, Stabenfeldt GH: Biology of ovarian cycles, pregnancy and pseudopregnancy in the domestic cat. J Reprod Fertil 1993, 47(Suppl):29-35

22. Scott PP: Reproduction and breeding techniques for laboratory animals. In Cats. Edited by Hafez ESE. Philadelphia: Lea \& Febiger; 1970.

23. Tsutsui T, Suzuki Y, Toyonaga M, Oba H, Mizutani T, Hori T: The role of the ovary for the maintenance of pregnancy in cats. Reprod Domest Anim 2009, 2:120-124

24. Stocco DM, Wang $X, Y_{0}$ J, Manna PR: Multiple signaling pathways regulating steroidogenesis and steroidogenic acute regulatory protein expression: more complicated than we thought. Mol Endocrinol 2005, 19:2647-2659.

25. Shille VM, Stabenfeldt GH: Luteal function in the domestic cat during pseudopregnancy and after treatment with prostaglandin $\mathrm{F}_{2 \mathrm{a}}$. Biol Reprod 1979, 21:1217-1223.

26. Feldman EC, Nelson RW: Canine and Feline Endocrinology and Reproduction. Philadelphia: W.B. Saunders Comp; 1996.

27. Johnston SD, Root Koostritz MV, Olson PN: Canine and Feline Theriogenology. Philadelphia: W.B. Saunders Comp; 2001

28. Kowalewski MP, Mason J, Howie AF, Morley SD, Schuler G, Hoffmann B: Characterization of the canine 3beta-hydroxysteroid dehydrogenase and its expression in the corpus luteum during diestrus. J Steroid Biochem Mol Biol 2006, 101:254-262

29. http://www.ncbi.nlm.nih.gov/genome/guide/cat/index.html.
30. Kowalewski MP, Hoffmann B: Molecular cloning and expression of StAR protein in the canine corpus luteum during dioestrus. Exp Clin Endocrinol Diabetes 2008, 116:158-161.

31. Zhao S, Fernald RD: Comprehensive algorithm for quantitative real-time polymerase chain reaction. J Comput Biol 2005, 12:1045-1062.

32. Lorence ML, Murry BA, Trant JM, Mason Jl: Human 3 $\beta$ - hydroxysteroid dehydrogenase $/ \Delta 5 \rightarrow 4$ isomerase from placenta: expression in nonsteroidogenic cells of a protein that catalyzes the dehydrogenation/ isomerization of C21 and C19 steroids. Endocrinology 1990, 126:2493-2498.

33. Clark BJ, Wells J, King SR, Stocco DM: The purification, cloning and expression of novel luteinizing hormone-induced mitochondrial protein in MA-10 mouse Leydig cells. Characterization of the steroidogenic acute regulatory protein StAR. J Biol Chem 1994, 269:28314-28322.

34. Bezler L: Expression zytoskeletaler Filamente und des vascular endothelial growth factor (VEGF) systems in der endotheliochorialen Plazenta von Hund und Katze. Giessen, Germany: Inaugural Dissertation of the Justus-LiebigUniversity; 2008

35. Tsang PCW, Walton JS, Hansel W: Oxytocin-specific RNA, oxytocin and progesterone concentrations in corpora lutea of heifers treated with oxytocin. J Reprod Fertil 1990, 89:77-84.

36. Skarzynski DJ, Jaroszewski JJ, Bah MM, Deptula KM, Barszczewska B, Gawronska B, Hansel W: Administration of a nitric oxide synthase inhibitor counteracts prostaglandin $\mathrm{F}_{2}$-induced luteolysis in cattle. Biol Reprod 2003, 68:1674-1681.

37. Schmidt PM, Chakraborty PK, Wildt DE: Ovarian activity, circulating hormones and sexual behavior in the cat. II Relationship during pregnancy, Parturition, Lactation and the Postpartum Estrus. Biol Reprod 1983, 28:657-670

38. Strauss JF III, Martinez F, Kiriakidou M: Placenta steroid hormone synthesis: unique features and unanswered questions. Biol Reprod 1996, 54:303-311.

39. Salon DS, Sherman MI: The biosynthesis of progesterone by cultured mouse midgestation trophoblast cells. Dev Biol 1975, 47:394-440.

40. Ben-Zimra M, Koler M, Melamed-Book N, Arensburg J, Payne AH, Orly J: Uterine and placental expression of steroidogenic genes during rodent pregnancy. Mol Endocrinol 2002, 16:1864-1880.

41. Thellin O, Coumans B, Zorzi W, Igout A, Heinen E: Tolerance to the foeto-placental 'graft': ten ways to support a child for nine months. Curr Opin Immunol 2000, 12:731-737.

42. Hoffman B, Schuler G: The bovine placenta; a source and target of steroid hormones: observations during the second half of gestation. Domest Anim Endocrinol 2002, 23:309-320.

43. Schuler G, Greven H, Kowalewski MP, Döring B, Ozalp GR, Hoffmann B: Placental steroids in cattle: hormones, placental growth factors or by-products of trophoblast giant cell differentiation? Exp Clin Endocrinol Diabetes 2008, 116:429-443.

44. Leiser R, Pfarrer C, Abd-Elnaeim M, Dantzer V: Feto-maternal anchoring in epitheliochorial and endotheliochorial placental types studied by histology and microvascular corrosion casts. Trophoblast Res 1998 12:21-39.

\section{doi:10.1186/1477-7827-10-89}

Cite this article as: Siemieniuch et al: Steroidogenic capacity of the placenta as a supplemental source of progesterone during pregnancy in domestic cats. Reproductive Biology and Endocrinology 2012 10:89.

\section{Submit your next manuscript to BioMed Central and take full advantage of:}

- Convenient online submission

- Thorough peer review

- No space constraints or color figure charges

- Immediate publication on acceptance

- Inclusion in PubMed, CAS, Scopus and Google Scholar

- Research which is freely available for redistribution 